\title{
ACQUISITION OF PROPERTY BY DISSOLVED CORPORATIONS DURING THE STATUTORY WINDING UP PERIOD*
}

Common law, having created a fictional life in corporate bodies, carried the analogy to its logical extreme and endowed them with a fictional death upon dissolution. ${ }^{1}$ This demise left no heirs to take over the estate of the deceased: pending suits were abated, ${ }^{2}$ debts were extinguished, ${ }^{3}$ and any property rights held by the corporation were immediately forfeited. ${ }^{4}$ Such results were relatively harmless at a time when the function of a corporation was merely to enable an ecclestiastical or municipal organization "to hold land

* Nardis Sportswear v. Simmons, 218 S.W.2d 451 (Tex. 1949).

1. See, e.g., Mumma v. Potomac Co., 8 Pet. 281, 286 (U.S. 1834); Greeley v. Smith, 10 Fed. Cas. No. 5,748, at 1075-6 (C.C.D.Me. 1845); 8 Thompson, CorpordTroNs $\$ \$ 6505-6$ (3d ed. 1927); 1 BL. Coms. *484. The common law rule persists where no applicable statute contravenes it. See, e.g., Chicago Title \& Trust Co. v. Wilcox Bldg. Corp., 302 U.S. 120, 125 (1937); Oklahoma Gas Co. v. Oklahoma, 273 U.S. 257,259 (1927).

2. E.g., Oklahoma Gas Co. v. Oklahoma, 273 U.S. 257 (1927); National Bank v. Colby, 21 Wall. 609 (U.S. 1874). See 16 Fletcher, Crclopedia Corporations $\S 8142$ (rev. ed. 1942); WaIt, Insolvent Corporations $\$ 379$ (1888). This rule is now generally made obsolete by statutory provisions, but still survives in a limited sphere through application to criminal suits. United States v. Safeway Stores, 140 F.2d 834 (10th Cir. 1944) (criminal citations under Sherman Act abated by reason of dissolution of defendant corporation). See Marcus, Suability of Dissolved Corporations, 58 HARV. L. REv. 675 (1945).

3. See 16 Fletcher, op. cit. supra note $2, \S 8127 ; 1 \mathrm{BL}$. Comar. $* 484$. It is doubtful whether this result was ever actually achieved in this country. See Marcus, supra note 2, at 677-80; Ballantine, Corporations $\$ 312$ (rev. ed. 1946). The obvious harshness of such a rule was excused by the statement that creditors must be presumed to understand the nature and incidents of the corporate body, and to contract with reference to them. See Mumma v. Potomac Co., 8 Pet. 281, 286 (U.S. 1834).

4. The traditional statement was that personal property escheated to the monarch, and real property reverted to the grantor. See $1 \mathrm{BL}$. CoMm. 326-7, n.21 (Cooley's $2 \mathrm{~d}$ cd. 1872); 8 Thompson, Corporations $\$ 6506$. Some commentators have insisted that this rule was never supported by adequate authority, but has simply been handed down from text to text as if true. See BaLrantine, Corporations $\$ 313$ (rev. ed. 1946); 16 FletcHen, $o p$. cit. supra note 2, $\$ 8134$; Note, 3 HARv. L. REv. 135 (1889). The rule has, however, been applied in this country to non-business corporations at least. E.g., Church v. United States, 136 U.S. 1 (1889) (church lands forfeited to the sovereign); Danville Seminary v. Mott, 136 Ill. 289, 28 N.E. 54 (1891) (lands of charitable organization reverted to donor). Material concerning the doctrine of reverter is collected in 47 A.L.R. 1288, 1328-55 (1927).

5. See Bacon v. Robertson, 18 How. 480, 487 (U.S. 1855). One of the earliest treatises on corporations devotes seventy pages to dissolution and its effect without mentioning a business corporation; examples used therein range from the Order of Templars to the City of London. 2 Kyd, Law of Corporations 446-516 (1794). Sec also Marcus, supra note 2 , at 678, n. 12. 
beyond the span of an individual's lifetime. ${ }^{6}$ Since corporations then had no stockholders, and few if any creditors, no sudden financial losses were incurred. ${ }^{7}$ But with the growth of a market-credit economy, corporate wealth became embodied in extremely complex legal relationships which could not be summarily terminated, and it became necessary to devise a method whereby corporate assets could be translated into money and distributed to creditors and stockholders. ${ }^{8}$

To meet this problem, states now have statutory provisions which endow dissolved corporations with a life after death. ${ }^{9}$ These statutes give the trustees of the corporation time in which to sue and be sued, to settle accounts and pay off debts, to dispose of corporate property, and generally to terminate the affairs of the corporation. ${ }^{10}$ During the time limit established by

6. "But, as all personal rights die with the person; and, as the necessary forms of investing a series of individuals, one after another, with the same identical rights, would be very inconvenient, if not impracticable; it has been found necessary . . . to constitute artificial persons, who may maintain a perpetual succession, and enjoy a lind of legal immortality." $1 \mathrm{BL}$. Cosins. $" 467$.

7. See, e.g., Mott v. Danville Seminary, 129 III. 403, 410, 21 N.E. 927,923 (1899); MIcAlhany v. Miurray, 89 S.C. 440, 44, 71 S.E. 1025,1026 (1911).

S. Courts early realized the necessity of protecting crediturs, and the common law treatment of dissolved corporations became shot through with exceptions, mainly thruugh the interference of equity. See cases collected in 47 A.L.R. 12:8, 1355-64 (1927); Ballantine, Corporations $\$ \$ 312-13$. The device uscd for preservation of assets was the concept of a trust fund for the benefit of creditors. The "trust fund" theory vas first developed by Justice Story in Wood v. Dummer, $30 \mathrm{Fed}$. Cas. 435, No. 17,944 (C.C.D.Me. 1824). Later this device was extended for the protection of the stollholders. E.g., Bacon v. Robertson, 18 How. 480 (U.S. 1855); sce Folger v. Columbian Ins. Co, 99 Miass. 267, 276-7 (1868).

While the trust fund concept protected creditors and stochholders from irresfunsible dissipation of assets by giving them a cause of action against the trustces, it was not designed to afford the trustees opportunity to talke the affirmative action necescary to achieve complete protection of parties who were still financially interested after dissolution.

9. E.g., ALA. CODE, tit. 10, $\$ 110$ (1940) (for five years, plus an additional fiveyear period upon application to the court); DEI. Cons, c. 65, $\$ 42$ (1935) (for three years, plus sufficient time to resolve all litigation commenced within the three-year period) ; N.Y. Stock CoRP. LAw $\$ 105$ (8) (for an indefinite period); One. Co:tr. Laws ANN. \$77-259 (Supp. 1947) (for five years with provision for extension for purpose of suits involving real estate). The provisions are usually coupled with one for the appointment of a trustee to handle litigation in the name of the corporation. E.g., KA:B. GEN. Stat. ANn. \$17-3607 (Corricl, Supp. 1947). A few states have not expressly extended the corporation's existence, but have made the directors of the corporation statutory trustees charged with responsibility for the assets during the winding up operation. E.g., Colo. Stat., c. 41, $\$ 62$ (1935). This last method constitutes codification of the equitable trust fund doctrine. See Hornstein, Toluntary Dissolution-A Aco Derclosment in Intracorporate Abuse, 51 YaLE L. J. 64, 71-5 (1941). Extensive, although out-of-date, material on the statutory provisions of each state is collected in 47 A.L.R. $1288,1397-1537$ (1927).

10. The language of the Texas statute is typical:

"Upon the dissolution of a corporation ... the president and directors ... shall 
the statute, it may become financially expedient for the trustees to enforce executory contracts and options. The disposal of property is specifically authorized. And in Nardis Sportswear $v$. Simmons ${ }^{11}$ the Texas Supreme Court recently interpreted the state winding-up statute ${ }^{12}$ to allow a dissolved corporation, even in the absence of specific authorizing language, to acquire property by enforcing an option during the statutory period of life after death.

In the Nardis case, the plaintiff corporation, a clothing manufacturer, held a five-year lease on certain Dallas real estate, with an option to purchase at a fixed price. At the time of dissolution, the lease had about two and a half years to run. The trustees subsequently sought to exercise the option, but since real estate values had risen since the signing of the lease, the lessor refused to execute a deed. In a suit for specific performance, a directed verdict by the trial court for the defendant lessor was affirmed by the Texas Court of Civil Appeals, principally on the theory that under the winding up statute a dissolved corporation was wholly without power to acquire property. ${ }^{13}$ The Supreme Court of Texas reversed, holding that the option to purchase land was an asset within the scope of the winding up

be trustees of the creditors and stockholders of such corporation, with power to settle the affairs, collect the outstanding debts, and divide the moneys and other property among the stockholders after paying the debts ... and for this purpose they may in the name of such corporation, sell, convey and transfer all real and personal property belonging to such company, collect all debts, compromise controversies, maintain or defend judicial proceedings, and exercise full power and authority of said company over such assets and property." TEx. Crv. STAT., tit. 32, art. 1388 (1925).

"The existence of every corporation may be continued for three years after its dissolution from whatever cause, for the purpose of enabling those charged with the duty to settle up its affairs." Id., art. 1389.

These statutes have been interpreted to permit actions which, at first glance, scem to have little bearing on disposal of assets in a strict sense. See, e.g., In re International Sugar Feed Co., 23 F.Supp. 197 (D.Minn. 1938) (dissolved corporation permitted to file petition for reorganization proceedings under $\$ 77 \mathrm{~B}$ of Bankruptcy Act) ; Bruun v. Cook, 280 Mich. 484, 273 N.W. 774 (1937) (election of new officers); Tenison v. Wilson, 151 S.W.2d 327 (Tex.Civ.App. 1941) (trustees allowed to organize new corporation to take over assets of dissolved corporation).

11. 218 S.W.2d 451 (Tex:' 1949).

12. Tex. Civ. Stat., tit. 32, art. 1388-9 (1925). See note 10 supra.

13. Nardis Sportswear v. Simmons, 213 S.W.2d 864 (Tex.Civ.App. 1948). The decision was partially based on the provisions of a Texas statute prohibiting a corporation from purchasing any land unless such land is necessary to enable the corporation to do business, or is acquired in due course of business to secure the payment of a debt. Tex. CIV. STAT., tit. 32, art. 1359 (1925). Moreover, the court felt very strongly that the winding up statute did not authorize a dissolved corporation to exercise an option to buy under any circumstances:

"Thus I think the conclusion inescapable that the dissolved corporation was wholly without power to purchase real estate, or anything else, as it was out of business, and its trustees were not authorized in the winding-up procedure to exercise powers greater than those remaining with the dissolved corporation." 213 S.W.2d 864, 872 (Tex.Civ.App. 1948). 
statute. It therefore survived dissolution of the corporation, and could be exercised if such action was necessary to settle properly the affairs of the dissolved corporation. ${ }^{14}$

This result gives concrete expression to the policy behind winding up statutes-the protection of creditors and the reimbursement of stoclsholders. ${ }^{15}$ Since creditors have a priority claim on the assets of the corporation, ${ }^{10}$ these statutes must, of course, be construed to favor them over stoclsholders. ${ }^{17}$ But where, as in this case, there is no conflict between creditors and stockholders, trustees should be permitted to reap the maximum gain for the stockholders. ${ }^{18}$ In the instant case, for example, the corporation had gone out of business, but was still obligated to pay rent for the unexpired term of the lease. ${ }^{19}$ And provisions in the lease made subletting or assign-

14. Nardis Sportswear v. Simmons, 218 S.W.2d 451 (Tex: 1949).

Analogous precedent affirmatively supports the Nardis decision. There has been no litigation directly on the problem of whether a dissolved corporation can buy land under a winding up statute. Dicta in opinions dealing with the question of survival of leases, however, have indicated that options to buy, such as that in the Nardis case, survive. Sce Chesnut v. Master Laboratories, 148 Neb. 378, 27 N.W.2d 541 (1947); Conn v. Manchester Amusement Co., 79 N.H. 450, 111 Atl. 339 (1920). But cf. Jaclison v. Western Union Telegraph Co., 269 Fed. 598 (5th Cir. 1921).

In Rhode Island Hospital Trust Co. v. American National Red Cross, 50 R. 461, 149 Atl. 581 (1930), a dissolved Visiting Nurse Association, bequeathed money under a will, was held capable of taking possession of the money on the condition that it manage to revive its charter before expiration of the statutory winding up period. While that condition seems to make the holding distinguishable, this case has bren cited as direct authority for the proposition that a corporation can acquire property after dissolution while acting under a winding up statute. See 16 FLETCHER, of cit. sispra nate 2 , $\$ 8171$, n. 9 ; Comment, 44 MirCE. L. Rev. 823, 826 (1946).

15. Courts generally consider these statutes remedial in nature and construe them liberally. See, e.g., NLRB v. Timken Silent Automatic Co., 114 F.21 449, 450 (2d Cir. 1940) ; Lynchburg Colliery Co. v. Gauley \& E. Ry., 92 W.V3. 144, 148, 114 S.E. 46?, 464 (1922). But see MIcBride v. Clayton, 140 Tex. 71, 75-6, 166 S.TW 2d 125, 123 (1942).

16. E.g., Hunn v. United States, 60 F.2d 430 (Sth Cir. 1932); Wilson v. Lueas, 185 Ark. 183, 47 S.W.2d 8 (1932); 16 FLETCHER, op. cit. sippro note $2, \$ 8219$, and cases cited therein. Such priority of claim is normally provided for expressly in state statutes. See, e.g., Texas statute, note 10 stpro.

Creditors may hold the trustees personally liable to the extent of the assets placed in their hands if they do not properly fufill their duties. Fox v. Radel Leather Mrg. Con 121 N.J.Eq. 291, 189 Atl. 366 (Ct.Err.\&App. 1937). Winding up statutes often expressly call for this personal liability. E.g., TEx. Crv. Star., tit. 32, art. 1383 (1925). See Hornstein, supra note 10; Comment, 45 HARv. L. REv. 1374, 1373 (1932).

17. See Beach v. Wharton Mining Co., 128 N.J.Eq. 192, 195, 15 A.2d 605, 607 (Ct.Err.SApp. 1940); Lyon-Gray Lumber Co. v. Gibraltar Life Ins. Co, 269 S.W. SD, 82 (Tex.Civ.App. 1925).

18. See cases cited notes 10 and 15 stspra; of. Bacon v. Robertson, 18 How. 480 (U.S. 1885).

19. That a lease survives dissolution is settled. Perry v. Shaw, 152 Fla. 765, 13 So.2d 811 (1943); Cummington Realty Associates v. Whitten, 239 Miss. 313, 132 N.E. 53 (1921); Conn v. Mianchester Amusement Co., 79 N.H. 450, 111 Atl. 339 (1920). 
ment impossible. ${ }^{20}$ The option was similarly unassignable. ${ }^{21}$ Therefore, only by exercising the option could the trustees protect the stockholders. ${ }^{22}$ And in view of the rise in real estate values which had occurred since the price had been set, purchase was a prudent business move.

Consistent with the desire to protect creditors and stockholders, courts have placed two types of restrictions on the powers of trustees acting under a winding up statute. First, action in bad faith, designed to benefit the trustees to the detriment of creditors and stockholders, is prohibited. ${ }^{20}$ There was no question of this in the Nardis case. Second, the action must be necessary to the winding up process. ${ }^{24}$ But this latter requirement has not been so rigidly interpreted as to prevent survival of potential property rights embodied in executory contracts. ${ }^{25}$ For instance, in Michigan an

And the duty of the corporate lessee to pay rent survives with it. People v. National Trust Co., 82 N.Y. 283 (1880).

20. The terms of the lease are given in detail in Nardis Sportswear v. Simmons, 213 S.W.2d 864, 865-6 (Tex.Civ.App. 1948).

21. Where a lease contains a provision against assignment, an option contained in the lease is not separable, and hence is also not assignable. Prichard v. Kimball, 190 Cal. 757, 214 Pac. 863 (1923); see cases cited in 38 A.L.R. 1172-3 (1925).

22. A possible alternative would be reincorporation for the purpose of holding the lease and exercising the option. It seems probable, however, that the formation of a new corporation for such a purpose would constitute assignment of the lease and forfeiture of the option rights. See Gatley v. Shockley, 215 Cal. 604, 12 P.2d 436 (1932); cl. Berrien County Fruit Exchange v. Pallas, 314 Mich. 66, 22 N.W.2d 74 (1946) (such action permitted where non-assignment clause had been stricken from the lease).

There was no way in which the Nardis corporation could use the premises for business purposes. Express prohibition against continuation of business as usual is included in several winding up statutes. DEL. CODE, c. $65, \S 42$ (1935); MASS. LAWs, c. 155, $\$ 51$ (1948); Mich. Stat., tit. 21, \$21.75 (1937); N.J. Stat. ANN. \$14:13-4 (1937). And where the prohibition is not express, it is implied. E.g., Houston v. Utah Lake Land, Water \& Power Co., 55 Utah 393, 187 Pac. 174 (1919); sec McBride v. Clayton, 140 Tex. 71, 75-6, 166 S.W.2d 125, 128 (1942).

23. The trustees must act in good faith to benefit all the stockholders, not mercly some of them. E.g., Mason v. Pewabic Mining Co., 133 U.S. 50 (1890). And they may not attempt to benefit themselves to the detriment of stockhoiders. E.g., Finch v. Finch, 68 Cal.App. 72, 228 Pac. 553 (1924) (trustee-stockholder accepted, in his capacity as trustee, his own stock for cancellation, thus increasing the liability of other stockholders); Young v. Blandin, 215 Minn. 111, 9 N.W.2d 313 (1943) (after liquidating assets in lump conveyance for $\$ 5,000,000$, trustee played stock market with proceeds). Nor may they act with the purpose of benefitting stockholders at the expense of creditors. Sec notes 16 and 17 supra.

24. See McLaughlin Land \& Livestock Co. v. Bank of America, 94 F.2d 491, 493 (9th Cir. 1938) ; Young v. Blandin, 215 Minn. 111, 117, 9 N.W.2d 313, 316 (1943); cases cited note 22 supra.

25. Executory contracts in general survive dissolution. E.g., Mayflower Realty Co. v. Security Savings \& Loan Soc., 192 Wash. 129, 72 P.2d 1038 (1937), modifitd on other groutsds, 75 P.2d 579 (1938). That the contract provides for a contingent property right seems to make no difference. See Bank of New York v. Kennedy, 183 Misc. 819, 54 N.Y.S.2d 122 (Sup.Ct. 1944) (bond secured by mortgage on real estate); of. Big Sespe Oil Co. v. Cochran, 276 Fed. 216 (9th Cir. 1921) (survival of right of redemption to real 
option to renew a lease has been held enforceable after dissolution, despite the fact that the new term extended beyond the period permitted for winding up. ${ }^{26}$ The only additional difficulty raised in the Nardis case was the conceptual point that the trustees' action was designed to convert a potential property right into actual "title". The problem facing the court was a practical one: should a dissolved corporation, whose existence had been prolonged for limited purposes by statute, be permitted to make $a$ "windfall" profit on an asset which had not been realized before dissolution? 77 Actually, however, no more of a "windfall" is involved in such action than in the disposal of inventory stocks which have risen in price. It is clear, moreover, that refusal to enforce the option would simply permit the lessor to escape the consequences of a bad bargain because of the purely fortuitous dissolution of the corporate lessee.

The court in the Nardis case reached a conclusion consonant with modern business realities. In planning ahead, a corporation must constantly malse and receive future commitments which embody within themselves profit expectations. If these commitments are abrogated, a portion of the corporate assets is effectively dissipated. By allowing a dissolved corporation to capitalize on the agreements made during its corporate life, the Nardis case affords creditors a fuller measure of protection and enables stockholders to receive the fruits of their original investment.

estate) ; Byers v. Black Mlotor Co., 65 Ga.App. 773, 16 S.E.2d 478 (1941) (execution of judgment by levy on personal property).

A contract which by its terms depends on the continuing ability of the corporation to do business, however, is extinguished upon the dissolution of the corporate party. E.g., Arnold v. Streck, 108 F.2d 387 (7th Cir. 1939).

26. Kay Furniture Co. v. Rovin, 312 XIich. 290, 20 N.W.2d 194 (1945).

27. The intermediate appellate court, in deciding that it should not, ealled the transaction "a real estate speculation pure and simple." Nardis Sportswear v. Simmons, 213 S.W.2d 864,872 (Tex.Civ.App. 194S). 